\begin{tabular}{|c|c|c|}
\hline $\bar{\sigma}$ & International Journal of Current Research in & \\
\hline & $\begin{array}{c}\text { Biosciences and Plant Biology } \\
\text { BSs }\end{array}$ & \\
\hline $\begin{array}{l}\text { EXCELLENT } \\
\text { PUBLISHERS }\end{array}$ & $\begin{array}{l}\text { J (Unme) } \\
\text { Journal homepage: www.ijcrbp.com }\end{array}$ & 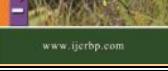 \\
\hline
\end{tabular}

\title{
Qualitative and Quantitative Screening of Vegetative Mycelium of Morchella Species for the Activity of Extracellular Enzymes in North West Himalayas
}

\author{
Monika Thakur* \\ Amity Institute of Food Technology, Amity University, Noida (UP) - 201 303, India \\ *Corresponding author.
}

\begin{abstract}
Among wild edible species of mushrooms, morels rank first in choice and delicacy and have been the mushroom of choice since ancient times in India and elsewhere. Seven different Morchella species (M. angusticeps, M. conica, M. crassipes, M. deliciosa, M. esculenta, M. tibelica and $M$. simlensis) have been qualitatively and quantitatively screened for different extracellular enzymes. Yellow morels produced qualitatively higher concentration of cellulase, amylase, pectinase and urease in comparison to black morels. Similarly, quantitatively, yellow morels showed maximum activity of extracellular enzymes viz. cellulose, amylase and protease than black morels. The study confirms higher extracellular enzyme polymorphism at inter specific levels and could distinguish yellow and black morels from each other. The production of all these enzymes shows that Morchella spp. are capable of degrading and utilizing various substrates such as cellulose, starch, urea, pectins and proteins efficiently and this can help the mycologists to opt such substrates for the domestication of the morels.
\end{abstract}

\section{Article Info \\ Accepted: 26May 2016 \\ Available Online: 06 June 2016}

\section{Keywords}

Extracellular enzymes

Morchella species

Quantitative screening

Vegetative mycelium

\section{Introduction}

Enzymes are water soluble, colloidal, organic macromolecules which are wholly and partially proteinaceous in nature, biological in origin and capable of catalyzing specific biochemical reactions under specific conditions of temperature and $\mathrm{pH}$. A variety of yeast, fungi and bacteria degrade a range of complex polymeric substances in soil by secretion of some extracellular enzymes. Fungi are the potent source of enzymes that are preferred over the enzymes produced by animals and plants (Fogarty and Kelly, 1979). Macro fungi (mushrooms) produces a wide range of extracellular enzymes and these enzymes enable them to degrade complex organic matter into soluble substances, which can then be absorbed by the mushrooms for the purposes of nutrition, actively or passively. Mushrooms are rich source of bioactive molecules (Wang and $\mathrm{Ng}$, 2006; Thakur, 2012; Thakur, 2015), polysaccharides and hydrolytic enzymes like cellulase, xylanase and laccases etc. (Cambria et al., 2000). Therefore, the growth and fruiting of any individual mushroom species on a particular waste material will depends largely upon the ability of that mushroom to produce enzymes which are essential to degrade the major components of the waste (or its growth substrate) and there after absorbs it as food. Therefore, fungi obtain much of their nutrition by extracellular enzymes.

Morels are among the most sought after wild, edible fungi throughout the world (Korf, 1973; Lakhanpal and Rana, 2005; Thakur, 2015). Mycologists have making sustained efforts since early times for cultivating morels. Interest in the cultivation of morels has increased as a 
result of recent biochemical and genetic studies (Ower, 1982; Ower et al., 1986). But besides all the studies and efforts the domestication of morels remains a challenge for mycologists. The taxonomic confusions in the genus Morchella have been tried to be resolved using methodologies beyond morphology (Rana, 2005; Lakhanpal et al., 2010). Since the set of enzymes of a mushroom species defines the set of substrate to be used and the varied culture conditions do not affect the repertoire of enzymes (Rai et al., 1990 and Cavazzoni and Manzoni et al., 1994). Gessner et al. (1987) used enzyme electrophoresis and classified $M$. deliciosa and $M$. esculenta as two polymorphic populations of the same species. Ower (1982) and Ower et al. (1986) observed that accomplishment of small-scale laboratory production and secretion of extracellular enzymes by Morchella esculenta and M. angusticeps enhances their possibilities of domestication. Kulkarni and Kamerath (1989) separated yellow and black morels using isozyme electrophoresis of NAD-glutamate dehydrogenase and glucose phosphate isomerase. Royse and May (1990) also separated yellow morels from black morels by analysing twelve different enzymes. Bunyard et al. (1994) placed morels in three broad groups based on their gross morphology: black morels (M. angusticeps, $M$. conica, and M. elata); yellow morels (M. esculenta, $M$. crassipes, and $M$. deliciosa) and semi free-capped morels (M. semilibera).

Singh et al. (2001) recorded the production of lignocellulotic enzymes by Morchella esculenta isolates have the potential to degrade and utililize cellulose, hemicellulose and lignin.

Kamal et al. (2004) studied the role of extracellular enzymes in initiating sexual cycle in three different species of Morchella viz. M. conica, M. angusticeps, and M. esculenta. They studied the variation in the production of different enzymes viz. cellulase, xylanase, $\beta$-glucosidase, laccase, polyphenol oxidase, peroxidase and suggested that morels are capable of degrading substrates such as lignin, cellulose and hemicellulose efficiently.

Tiwari et al. (2004) compared the enzyme profile of seven species of Morchella viz. M. esculenta, $M$. angusticeps, $M$. conica, $M$. crassipes, $M$. spongicola, $M$. vulgaris and related genera such as Mitrophora semilibera and Verpa conica for seven extracellular enzymes. The species of genus Morchella produced significantly higher quantities of cellulase and xylanase in comparison to the related genera Mitrophora and
Verpa. Black morels produced significantly higher amounts of laccase in comparison to yellow morels. This study confirmed higher extracellular polymorphism at inter specific than at intra specific levels. The polymorphism in enzyme profiles could distinguish yellow morels, black morels and related genera from each other. Singh et al. (2007) studied the extracellular enzymatic activities by Pleurotus species on vegetable wastes. Papinutti and Lechner (2008) studied the influence of carbon source on the growth of lignocellulotic enzyme production by $M$. esculenta strains. Lakhanpal et al. (2010) also studied the qualitative and quantitative screening of four different species of morels viz. $M$. angusticeps, M. conica, $M$. deliciosa and M. esculenta for five different extracellular enzymes - amylase, cellulase, pectinase, protease and lipase production. The production of all the test enzymes was recorded to be higher in yellow morels in comparison to black morels. All the species showed negative results for lipase production.

In North West Himalayas, seven different molecular characterized Morchella species have been present viz. $M$. angusticeps, M. conica, M. crassipes, M. deliciosa, M. esculenta, M. tibelica and M. simlensis (Lakhanpal et al., 2010; Thakur and Lakhanpal, 2013; Thakur and Lakhanpal, 2014). Therefore, the screening of the qualitative and quantitative production of extracellular enzyme by all the Morchella species has been mandatory. The present research work has been carried to screen all the existing species of morels for degrading various substrates, which can provide vital clues for the selection of substrates for its cultivation in North West Himalaya region.

\section{Materials and methods}

The vegetative mycelium of different species of Morchella has been grown in four different solid and liquid cultures as - Potato Dextrose Agar, Yeastal Potato Dextrose, Glucose Asparagine solution and Czapeck's Solution for 15 days in dark at $24^{\circ} \mathrm{C}$ without shaking.

\section{Qualitative screening of vegetative mycelium of} Morchella species

All the seven different Morchella species were screened for five different extracellular enzymes - Amylase, Cellulase, Pectinase, Lipase and Urease. All the seven species of Morchella were tested for their ability to produce different extracellular enzymes by the qualitative tests described by Hutchinson and Malloch (1988). 


\section{Amylase test agar}

For the screening of amylase, Modified Melin-Norkans (MMN) media (Marx, 1969) was prepared by using $2 \mathrm{~g} / \mathrm{l}$ of soluble starch instead of glucose and poured into plates. The mycelium of Morchella species were inoculated and incubated at $27^{\circ} \mathrm{C}$ for 2-3 weeks. After 4 weeks of incubation, the plates were flooded with iodine solution $(5 \mathrm{~g} \mathrm{KI}$ and $1.5 \mathrm{~g} / 100 \mathrm{ml}$ of water). The occurrence of a clear zone around the colony indicates the presence of amylase.

\section{Cellulase test agar}

Cellulase enzyme presence was estimated by using MMN media containing $0.1 \%$ carboxy methyl cellulose (CMC) instead of glucose was prepared and poured into petri plates. The mycelial discs ( $3 \mathrm{~mm}$ diameter) of all the seven species of Morchella were inoculated individually in each petri plate and incubated at $28^{\circ} \mathrm{C}$ for $1-2$ weeks. If cellulase enzyme has been produced, a clear zone will be formed surrounding the colony, which can be visualized with Congo red dye.

\section{Pectinase test agar}

The production of pectinase was estimated by using MMN medium containing $5 \mathrm{~g}$ of pectin/l was used. After inoculation with mycelial disc of respective Morchella species, the plates were incubated for $2-3$ weeks at $27^{\circ} \mathrm{C}$ and then these plates were flooded for 12 hours with Congo red dye. If pectinase has been produced, a clear zone will occur around the colony otherwise opaque background will be observed.

\section{Lipase test agar}

For the screening of lipase, MMN medium was prepared with $0.1 \mathrm{~g}$ of $\mathrm{CaCl}_{2}$ rather than $0.05 \mathrm{~g} / \mathrm{l}$. Tween 20 was autoclaved separately and added to the medium at a rate of $10 \mathrm{ml} / \mathrm{l}$ before pouring into plates. The mycelium of different Morchella spp. were inoculated and incubated at $27^{\circ} \mathrm{C}$ for $2-3$ weeks. The breakdown of Tween 20 would result in precipitation of $\mathrm{CaCl}_{2}$ crystals in the medium around and below the colony if there is the production of lipase by the mycelium.

\section{Urease test agar}

For the screening of urease, MMN medium with $5 \mathrm{~g}$ glucose $/ 1,0.02 \mathrm{~g} / 1$ phenol red and without ammonium phosphate was prepared in $900 \mathrm{ml}$ of water. Separately
$20 \mathrm{~g}$ of urea was added to $100 \mathrm{ml}$ of water and then sterilized. This was added to $900 \mathrm{ml}$ of autoclaved medium to make 1litre, 2-3 drops of $\mathrm{HCl}$ were added and swirled until medium turned yellow in color, and then poured into plates. After that the mycelium of Morchella species was inoculated in the petri plates containing medium. If urease enzyme was produced, the medium would turn into red.

\section{Quantitative screening of vegetative mycelium of Morchella species}

For quantitatively screening for vegetative mycelium of Morchella species for three different extracellular enzymes - amylase, cellulase, and protease, Macris and Galiotou-Panayotou's (1986) medium was prepared.

For each enzyme, specific enzyme source was used. 1\% starch for amylase enzyme, $1 \%$ casein for protease enzyme and $1 \%$ cellulose powder for cellulase enzyme were added in the separate flasks having Macris and Galiotou- Panayotou's medium. Double distilled water was added in the each flask to make the volume 1 litre and the $\mathrm{pH} 5.0$ was adjusted with the help of N/10 NaOH or $\mathrm{N} / 10 \mathrm{HCl}$. The media were sterilized at $15 \mathrm{psi}$ for $30 \mathrm{~min}$.

Three-three discs of mycelium of Morchella spp. were added to $100 \mathrm{ml}$ medium in $250 \mathrm{ml}$ Erlenmeyer flasks. These were incubated at $25^{\circ} \mathrm{C}$ for $8-10$ days and the cultures were then centrifuged at $10,000 \mathrm{rpm}$ for 20 minutes. The supernatant was collected and stored in refrigerator for further assay of respective extracellular enzymes, viz., amylase, protease and cellulase. The activity of the enzymes was expressed in terms of $\mu \mathrm{mole} / \mathrm{ml} / \mathrm{min}$ (IU).

\section{Amylase assay}

Amylase assay was determined according to the method of Reese and Mendel (1963) and Miller (1959). $0.5 \mathrm{ml}$ of starch solution, $0.3 \mathrm{ml}$ of phosphate buffer $(0.1 \mathrm{M}, \mathrm{pH} 7.0)$ and $0.2 \mathrm{ml}$ of enzyme solution were added. Contents were incubated at $55^{\circ} \mathrm{C}$ for $5 \mathrm{~min}$., cooled to room temperature and added 3ml of DNSA (Dinitro salicylic acid) reagent to each tube; $0.2 \mathrm{ml}$ of enzyme solution was added to the control tube and heated in boiling water bath for $30 \mathrm{~min}$. After cooling to room temperature, absorbance (OD) at $540 \mathrm{~nm}$ was measured against a reagent blank. The amylase enzyme activity was defined as the amount of the enzyme that released 1 mole of maltose from starch/minute under the assay conditions. Standard curve was prepared from $1 \mu$ mole to $100 \mu$ mole of maltose. 


\section{Protease assay}

Protease assay was determined by using Manachini et al. (1988) method. Briefly, $4 \mathrm{ml}$ of casein solution and $1 \mathrm{ml}$ of enzyme solution was added and incubated at $55^{\circ} \mathrm{C}$ for 15 minutes. The reaction was terminated by adding $5 \mathrm{ml}$ of 5\% trichloroacetic acid and the precipitates formed were removed by filtration using Whatmann filter paper No.1. Absorbance (OD) was measured at $275 \mathrm{~nm}$ against reagent blank containing $1 \mathrm{ml}$ double distilled water. The Enzyme activity was calculated as, one unit of proteolytic activity was defined as the amount of enzyme that released $1 \mu$ mole of tyrosine from casein/minutes under assay conditions. Standard curve was prepared from $1 \mu$ mole to $100 \mu$ mole of tyrosine, following the same procedure.

\section{Cellulase CMCase assay}

The total cellulose activity was determined by using Reese and Mendel (1963) and Miller (1959) method. Briefly, $0.5 \mathrm{ml}$ of enzyme preparation, $4.5 \mathrm{ml}$ of carboxymethylcellulose solution $[1 \%$ Carboxymethyl cellulose (CMC) in citrate buffer (0.055 M, pH 4.0)] was added. The control was also run with all components except enzyme. These were incubated at $55^{\circ} \mathrm{C}$ for 15 min., cooled to room temperature and $0.5 \mathrm{ml}$ of enzyme preparation was added to the control. One $\mathrm{ml}$ of mixture was withdrawn from the reaction mixture and $3 \mathrm{ml}$ of DNSA reagent was added to each tube. The mixture was heated in boiling water bath for $45 \mathrm{~min}$. After cooling to room temperature, absorbance (OD) was measured at $540 \mathrm{~nm}$ against a reagent blank. The Enzyme activity was calculated as, one unit of cellulase activity was defined as the amount of enzyme that released $1 \mu$ mole of D-glucose from $\mathrm{CMC} /$ minute under assay conditions. Concentration of reducing sugars was calculated from a standard curve of D-glucose $(20 \mu \mathrm{g}-200 \mu \mathrm{g} / \mathrm{ml})$.

\section{Results and discussion}

\section{Qualitative screening of vegetative mycelium of Morchella species}

All the seven different Morchella species viz. M. angusticeps, M. conica, M. crassipes, M. deliciosa, M. esculenta, $M$. tibelica and $M$. simlensis were qualitatively screened for the production of five extracellular enzymes. All the species investigated showed positive results for the production of cellulase, pectinase, amylase and urease but were negative to the production of lipase. The qualitative screening of extracellular enzymes profile has been presented in Table 1.

Table 1. Qualitative screening of extracellular enzymes from vegetative mycelium of Morchella spp.

\begin{tabular}{|c|c|c|c|c|c|c|c|}
\hline \multirow{2}{*}{ Enzymes } & \multicolumn{3}{|l|}{ Black morels } & \multicolumn{4}{|c|}{ Yellow morels } \\
\hline & M. angusticeps & M. conica & M. tibelica & M. esculenta & M. crassipes & M. deliciosa & M. simlensis \\
\hline Amylase & + & + & + & ++ & ++ & ++ & ++ \\
\hline Cellulase & + & + & + & ++ & ++ & ++ & ++ \\
\hline Pectinase & + & + & + & ++ & ++ & ++ & ++ \\
\hline Urease & + & + & + & ++ & ++ & ++ & ++ \\
\hline
\end{tabular}

When all the species were compared, M. angusticeps, $M$. conica, and $M$. tibelica (black morels) exhibited lesser production of cellulase, amylases, pectinase and urease than M. crassipes, M. esculenta, M. deliciosa and M. simlensis (yellow morels). All the species showed negative results for lipase. From these investigations, it was observed that yellow morels were able to utilize different carbon sources and produces extracellular enzymes better than black morels. Thus the observations inferred that yellow morels showed higher production levels for different extracellular enzymes than black morels.

No such work on qualitative screening of extracellular enzymes was carried out in Morchella spp. earlier. But similar studies were carried out on the qualitative screening of extracellular enzymes in Cantharellus cibarius, an ectomycorrhizal mushroom. The mycelium of $C$. cibarius was investigated for five enzymes, viz. cellulase, pectinase, amylase, urease and lipase and showed positive results to all of them (Sharma, 2002).

\section{Quantitative screening of vegetative mycelium of Morchella species.}

The vegetative mycelium of seven different Morchella species viz., $M$. angusticeps, $M$. conica, $M$. crassipes, $M$. deliciosa, M. esculenta, M. tibelica and $M$. simlensis were screened for the production of three different 
extracellular enzymes: amylase, cellulase and protease. The activity of these respective enzymes was checked in supernatant portion. The enzyme profile of all the species has been presented in Table 2 .

Table 2. Quantitative screening of extracellular enzymes from vegetative mycelium of Morchella spp.

\begin{tabular}{|c|c|c|c|c|c|c|c|}
\hline \multirow{2}{*}{ Enzymes* } & \multicolumn{3}{|l|}{ Black morels } & \multicolumn{4}{|c|}{ Yellow morels } \\
\hline & M. angusticeps & M. conica & M. tibelica & M. esculenta & M. crassipes & M. deliciosa & M. simlensis \\
\hline Amylase & 0.04 & 0.03 & 0.02 & 0.05 & 0.04 & 0.05 & 0.09 \\
\hline Cellulase & 0.001 & 0.008 & 0.002 & 0.02 & 0.03 & 0.03 & 0.05 \\
\hline Protease & 0.073 & 0.075 & 0.092 & 0.14 & 0.15 & 0.09 & 0.18 \\
\hline
\end{tabular}

$*=$ activity of enzymes are given in IU (International Units); Incubation period: 7 -12 days.

The amylase activity was found to be maximum (0.09 units) in $M$. simlensis and minimum (0.02 units) in $M$. tibelica. The protease activity was again maximum in (0.18 units) in $M$. simlensis and minimum in $(0.073$ units) in $M$. angusticeps. The maximum activity of cellulase (0.05 units) was observed in M. simlensis and minimum activity (0.001 units) was observed in $M$. angusticeps.

After screening all the three selected enzymes, it was found that the maximum activity was observed in protease, and then followed by cellulase and amylase. Yellow morels showed maximum activity of extracellular enzymes than black morels. So, the enzyme profiles also revealed the interspecific enzyme polymorphism in Morchella spp.

Certain other studies were also carried out previously to check the extracellular enzyme screening in different Morchella species. Kulkarni and Kamerath (1989) separated yellow and black morels using isozyme electrophoresis of NAD-glutamate dehydrogenase and glucose phosphate isomerase. Royse and May (1990) also separated yellow morels from black morels by analysing twelve different enzymes. In a similar study, Singh et al. (2001) recorded the production of lignocellulotic enzymes by Morchella esculenta isolates and noticed that $M$. esculenta is capable of degrading and utililizing cellulose, hemicellulose and lignin.

Kamal et al. (2004) observed similar types of observations while screening different extracellular enzyme production by Morchella spp. Seven different enzymes viz. cellulase, xylanase, $\beta$-glucosidase, laccase, polyphenol oxidase and peroxidase were produced by three Morchella spp. and suggested that morels are capable of degrading substrates such as lignin, cellulose and hemicellulose efficiently. Tiwari et al. (2004) reported the enzyme profile of eight species of Morchella and the related genera for seven different extracellular enzymes. They observed that cellulase production was higher in yellow morels $(M$. esculenta, $M$. crassipes and $M$. deliciosa) than black morels ( $M$. angusticeps and $M$. conica) and the related genera. Thus on the basis of the enzyme profiles, developed during present investigations, yellow and black morels can be separated from each other. The results of the present study confirms that polymorphism at interspecific levels are higher in respect of all extracellular enzymes. With the production of all the selected three enzymes (cellulase, amylase and protease), it was inferred that Morchella spp. are capable of degrading and utilizing various specific substrates viz. cellulose, starch, urea, pectins and proteins more efficiently.

\section{Conclusion}

On the basis of the qualitative and quantitative screening of enzyme profiles, developed during present investigations, yellow and black morels can be separated from each other. The results of the present study confirms that polymorphism at interspecific levels are higher in respect of all extracellular enzymes. The production of all these enzymes shows that Morchella spp. are capable of degrading and utilizing substrates such as cellulose, starch, urea, pectins and protein efficiently and this can help the mycologists to opt such substrates for the domestication of the species.

\section{Conflict of interest statement}

Authors declare that they have no conflict of interest.

\section{Acknowledgement}

The author gratefully acknowledge the support provided by Prof. T. N. Lakhanpal, Department of Biosciences, Himachal Pradesh University, Summer Hill, Shimla-171 005, India. 


\section{References}

Bunyard, B. A., Nicholson, M.S., Royse, D. J., 199. A systematic assessment of Morchella using RFLP analysis of the 28S ribosomal RNA gene. Mycologia 86, 762-772.

Cambria, M., Cambria, A., Ragusa, S., Rizarelli, E., 2000. Production purification and properties of an extracellular laccase from Rhizopogon lignosus. Protein Expr. Purif. 18, 141-147.

Cavazzoni, V., Manzoni, M., 1994. Enzyme analysis. Lebensmittel-Wissenschaft Technol. 27, 73-77.

Fogarty, W. M. and C. T. Kelly., 1979. Starch degrading enzymes of microbial origin. Proc. Ind. Microbiol. 15, 87-105.

Gessner, R. V., Romano, M. A., Schultz, R. W., 1987. Allelic variation and segregation of Morchella deliciosa and Morchella esculenta. Mycologia. 79, 683-687.

Hutchinson, L. J., Malloch, D. W., 1988. A verification of protocol for cultural isolates of ectomycorrhizal basidiomycetes. Mycol. Res. 102, 67-72.

Kamal, S., Singh, S. K, Tiwari, M., 2004. Role of enzymes in initiating sexual cycle in different species of Morchella. Ind. Phytopath. 57, 18-23.

Korf, R. P., 1973. Discomycetes and Tuberales. In: The Fungi Vol. IV A. Academic Press, New York.

Kulkarni, R. K., Kamerath, C. D., 1989. Isozyme analysis of Morchella species. Mush. Sci. 12, 451-457.

Lakhanpal, T. N., Shad, O., Rana, M., 2010. Biology of Indian Morels. I.K. International Publishing House, New Delhi.

Lakhanpal, T. N., Rana, M., 2005. Medicinal and nutraceutical genetic resources of mushrooms. Plant Gen. Res. - Charac. Uti. 81-20: 19, 1-17.

Macris, B. J., Galiotou-Panayotou, M., 1986. Enhanced cellobiohydrolase production from Aspergillus ustus and Trichoderma harzianum. Enzyme Microb. Technol. 8, 141144.

Manachini, P. L., Fortina, M. G., Parini, C., 1988. Thermostable alkaline protease produced by Bacillus thermoruber a new species of Bacillus. Appl. Microbiol. Biotechnol. 28, 409413.

Marx, D. H., 1969. The influence of ectotrophic mycorrhizal fungi on the resistance of pine roots to pathogenic infections.1. Antagonism of mycorrhizal fungi to root pathogenic fungi and soil bacteria. Phytopathol. 59, 153-163.

Miller, G. L., 1959. Dinitrosalicylic acid reagent for determination of reducing sugar. Anal. Chem. 31, 426-428.

Ower, R. D., Mills, G. L., Malachowski, J. A., 1986. Cultivation of Morchella. US Patent No. 4594809. Proc. Ind. Microbiol. 15, 87-105.

Ower, R., 1982. Notes on the development of morel ascocarp: Morchella esculenta. Mycologia. 74, 142-44.
Papinutti, L., Lechner, B., 2008. Influence of the carbon source on the growth of lignocellulotic enzyme production by Morchella esculenta strains. Appl. Microbiol. Biotechnol. 35, 1715-1721.

Rai, R. D., Vijay, B., Saxena, S., 1990. Production of extracellular enzymes by mesophilic fungi of mushrooms compost. Indian Phytopath. 43, 542-546.

Rana, M., 2005. Ethnobotanical studies on morels of district Kinnaur, H.P. M.Phil. Dissertation, Himachal Pradesh University, Summer Hill, Shimla.

Reese, E. T., Mendel, M., 1963. Enzymatic hydrolase of cellulase and its derivatives. In: Methods in Carbohydrate Chemistry. Academic Press, London.

Royse, D. J., May, B., 1990. Interspecific allozymes variation among Morchella spp. and its inference for systematics with in the genus. Biochem. Syst. Ecol. 18, 475-479.

Singh, M.P., Srivastava, A. Kr., Viswakarma, S. Kr., Pandey, V. Kr., Pandey, A. Kr., Singh, S. Kr., 2007. Extracellular enzymatic activities by Pleurotus species on vegetable wastes. Mus. Res. 16, 93-97.

Singh, S. K., Rai, R. D., Rai, A. K., Verma, R. N., 2001. Production of extracellular lignolytic enzymes by Morchella esculenta. Mush. Res. 10, 99-102.

Sharma, S., 2002. Physiological and molecular characterization of edible ectomycorrhizal fungus Cantharellus cibarius. M.Sc. dissertation, Department of Biotechnology and Environmental Sciences, TIET, Patiala.

Thakur, M. 2015. Wild Mushrooms as Natural Untapped Treasures. Natural products: Recent Advances. Write \& Print Publications, New Delhi. pp.214-226.

Thakur, M., 2012. Mushrooms: A prominent source of nutraceuticals. J. Food Process. Technol. 3(10), 178.

Thakur, M., Lakhanpal, T. N., 2013. Qualitative and quantitative screening of vegetative mycelium of Morchella species for the activity of extracellular enzymes. Indian Mushroom Conference on Diversification to Diversity for Nutritional and Environmental Security held during 16-17 April, 2013 at PAU, Ludhiana (Punjab), India.

Thakur, M., Lakhanpal, T. N., 2014. Qualitative phytochemical screening, Total phenolic content and in-vitro antioxidant activity in methanolic extracts of Morchella esculenta Fr. $8^{\text {th }}$ International Conference on Mushroom Biology and Mushroom Products (ICMBMP8) $19^{\text {th }}-22^{\text {nd }}$ Nov, 2014, New Delhi.

Tiwari, M., Singh, S. K., Kamal, S., Singh, S., Yadav, M. C., 2004. Extracellular enzyme polymorphism in Morchella and related species. J. Mycol. Pl. Pathol. 36, 64-68.

Wang, H.X., Ngo, T.B., 2006. Purification of laccase from fruiting bodies of the mushroom Pleurotus eryngii. Appl. Microbiol. Biotechnol. 69, 521-525.

\section{How to cite this article:}

Thankur, M., 2016. Qualitative and quantitative screening of vegetative mycelium of Morchella species for the activity of extracellular enzymes in North West Himalayas. Int. J. Curr. Res. Biosci. Plant Biol. 3(6), 123-128. doi: http://dx.doi.org/10.20546/ijcrbp.2016.306.015 